UDK: 94(510)+32

\title{
Mandžurska politika urejanja mednarodnih odnosov s posebnim ozirom na kantonsko trgovino
}

\author{
Marija ŠULER*
}

\section{Izvleček}

Propad domače dinastije Ming sredi sedemnajstega stoletja predstavlja pomembno zgodovinsko prelomnico na razvojni poti Kitajske. Prenos in konsolidacija dinastične oblasti v rokah tujih, mandžurskih zavojevalcev sta sovpadala $\mathrm{z}$ vse večjo prisotnostjo zahodnoevropskih trgovcev, misijonarjev in raziskovalcev, ki so na Kitajsko prihajali po morju, kakor tudi s kopenskim prodiranjem Rusov proti obalam Tihega oceana. Eni in drugi so prinašali znamenja nekih drugih civilizacij, ki pa so onkraj zidu trčila ob tradicionalne nazore o superiornosti in samozadostnosti kitajske države. Pričujoči članek spremlja razvoj ustreznih direktiv in praks, ki jih je glede urejanja meddržavnih političnih in trgovinskih odnosov formulirala osrednja mandžurska oblast, in ki so vsekakor pomembno vplivale tudi na vzpon in propad sistema kantonske trgovine.

Ključne besede: mandžurska dinastija, Kanton, evropska trgovina, kitajske restrikcije, evropski merkantilistični ekspanzionizem

\begin{abstract}
The decline of the native Ming Dynasty in the middle of the seventeenth century historically represents an important turning point in China's developmental path. The transmission and consolidation of the dynastic rule in the hands of foreign Manchurian conquerors coincided with the growing presence of West-European merchants, missionaries and researchers that were arriving to China by sea. At the same time, the Russians advanced by land towards the shores of the Pacific Ocean. Both of them carried along signs of different civilizations that would eventually, beyond the Great Wall, strike against traditional principles of Chinese superiority and self-sufficiency. The present
\end{abstract}

\footnotetext{
* Marija Šuler, doktorska študentka, Oddelek za azijske in afriške študije, Filozofska fakulteta, Univerza v Ljubljani. Elektronski naslov: meri.suler@gmail.com
} 
article follows the development of particular directives and practices which were formulated by the central Manchurian authorities to manage affairs regarding international political and trade relations. These directives were at the same time an important factor in the rise and fall of the Canton system of trade.

Keywords: Manchurian Dynasty, Canton, European trade, Chinese restrictions, European mercantile expansionism

\section{Uvod}

Eno izmed obdobij kitajske zgodovine, ki je tako v zahodnih kakor tudi v kitajskih zgodovinskih razpravah doživelo neverjetno število različnih interpretacij, je obdobje tako imenovanega sistema kantonske trgovine (Guangzhou tixi 广州体 系), ki svoje začetke beleži že v poznem sedemnajstem stoletju ${ }^{1}$.

Formalno je sicer omenjeni sistem stopil v veljavo leta 1757, ko je cesar Qianlong 乾隆 izdal edikt, s katerim je vse zunanjetrgovinske dejavnosti z izjemo ruske in japonske omejil na pristanišče v Kantonu. Delovanje tujih trgovcev je bilo poslej urejeno s strogimi državnimi predpisi, ki so določali, da se smejo tujci v Kantonu zadrževati le v predelih, kjer so imeli svoja skladišča. Tja niso smeli pripeljati svojih žena, določila cesarskega odloka so tujcem prepovedovala tudi uporabo nosilnic, čolnarjenje po reki, najemanje ženskih služabnic, kupovanje kitajskih knjig ter učenje kitajskega jezika. Ena glavnih značilnosti tega sistema trgovanja pa je bila njegova monopolistična struktura. Država je namreč pooblastila 13 trgovskih združenj yang hang 洋行, preko katerih so morali svoje posle opravljati vsi tuji trgovci. Velika neuravnoteženost $\mathrm{v}$ trgovanju (Kitajska namreč zaradi svoje samozadostnosti skoraj ni potrebovala tujih izdelkov), podvrženost tujcev arbitrarnemu kitajskemu pravu, ki ni poznalo legalnih pravic obtoženca, ter prakse, ki so predstavnikom zahodnih držav onemogočale svobodno trgovanje, so povzročali spore med tujimi trgovci in kitajsko upravo. Zahodne

\footnotetext{
${ }^{1}$ Večina zgodovinskih razprav, katerih predmet preučevanja je kantonski sistem trgovine, v ospredje postavlja politične direktive, ki jih je glede trgovanja v Kantonu izdajal mandžurski dvor. Na tem mestu je potrebno opozoriti, da so bile lokalne oziroma neformalne prakse podkupljivih kantonskih uradnikov in trgovcev usmerjene predvsem $\mathrm{v}$ zagotavljanje čim večjega dobička in so se tako $\mathrm{v}$ marsičem razlikovale od predpisanih uradnih oziroma formalnih političnih določb. Večina zgodovinarjev za začetek sistema kantonske trgovine navaja letnico 1757, ko je mandžurski cesarski dvor izdal odlok, da bo Kanton edino odprto pristanišče za zunanjo trgovino, Van Dyke pa zagovarja mnenje, da so se osnovni mehanizmi trgovanja razvili že do poznega sedemnajstega stoletja, ter da pred in po letu $1757 \mathrm{v}$ strukturi trgovanja ni bilo bistvenih sprememb; sam zato kantonski sistem trgovine časovno uvrsti med leti 1700 in 1842. (prim. Van Dyke 2005, 10, 185)
} 
države so zahtevale mednarodne odnose, ki bi bili zasnovani na podlagi evropskega prava, zahodnih diplomatskih načel ter svobodnega trgovanja, Kitajska pa njihovim zahtevam ni želela ugoditi. Nesoglasja so kulminirala v prvi opijski vojni (1840-1842), ki s svojo časovno razmejitvijo obeležuje formalen propad tega posebnega tipa trgovanja. (prim. Saje 2004, 53-54)

Nedvomno gre za edinstveno obdobje kitajske preteklosti, ki je zbudilo zanimanje številnih zgodovinarjev širom sveta in ki je imelo daljnosežne posledice ne samo za nadaljnjo razvojno pot Kitajske, temveč tudi za svetovno trgovino nasploh. Paul A. Van Dyke v svoji knjigi The Canton Trade: Life and Enterprise on the China Coast, 1700-1845 zagovarja tezo, da je sistem kantonske trgovine bil eden izmed najbolj pomembnih dejavnikov za rast modernih "globalnih» ekonomij:

The Canton Trade was one of the most important contributors to the rise of modern "global" economies. From 1700 to 1842, the foreign demand for tea and porcelain grew with each passing decade, and China continued to meet the demand with an ever-expanding supply. As the tea trade developed, world markets became more integrated; as investment capital continued to flow into China in ever increasing quantities, international financial structures became more sophisticated; as the global movements of silver and commodities became more structured, global commerce became more regular. Greater consistency, in turn, helped to reduce risks, which increased profits and made costs easier to assess. As costs stabilised and profits grew, international commerce attracted more investors. (Van Dyke 2005, 161)

Kantonska trgovina je bila eden izmed pomembnih dejavnikov, ki so doprinesli k vzponu sodobnih »globalnih « ekonomij. Med letoma 1700 in 1842 je tuje povpraševanje po čaju in porcelanu naraščalo iz desetletja $\mathrm{V}$ desetletje, Kitajska pa je na te zahteve odgovarjala $\mathrm{z}$ vse večjo ponudbo. Ko se je razvilo trgovanje s čajem, so svetovni trgi postali medsebojno bolj povezani; ko so kapitalske naložbe na Kitajskem vse bolj naraščale, so mednarodne finančne strukture postale bolj prefinjene; ko so globalni pretoki srebra in blaga postali bolj strukturirani, je tudi globalno trgovanje postalo bolj ustaljeno. Večja ustaljenost $\mathrm{v}$ trgovanju je po drugi strani pomagala zmanjšati tveganja, to pa je povečalo dobičke ter omogočilo lažjo oceno stroškov. Stabilizacija stroškov in večanje dobičkov sta $\mathrm{v}$ mednarodno trgovanje pritegnila več vlagateljev.

Sistem kantonske trgovine tvori izredno specifično obdobje kitajske preteklosti tudi zato, ker se je sploh prvič v zgodovini te ogromne države zgodilo, da je Cesarstvo sredine malo bolj na široko odprlo duri zunanjemu svetu. Družbeni, gospodarski, politični in kulturni procesi, ki so potekali v tem obdobju, so 
zagotovo bili eden izmed ključnih dejavnikov, ki so sprožili oblikovanje nove, moderne Kitajske.

Za študij kantonskega sistema trgovanja je na voljo veliko število pisnih virov. Med letoma 1690 in 1845 je na Kitajsko prihajalo na stotine tujih ladij, večina kapitanov, pomorščakov in trgovcev, ki so pluli na njih, pa so pisali in hranili ladijske dnevnike, ki danes pričajo ne samo o njihovih potovanjih, temveč tudi o poslovanju in stikih s Kitajci ${ }^{2}$. Dokumente iz tega obdobja danes hranijo arhivi širom po Ameriki, Evropi in Kitajski. Tako je bilo v zadnjih 150 letih o tej tematiki v raznih jezikih napisanih mnogo knjig in člankov, ki jih lahko glede na ožjo obravnavano problematiko v grobem razdelimo v 4 skupine: (1) dela, ki se osredotočajo na posamezno trgovsko družbo ali narodno pripadnost trgovcev (Vzhodnoindijska družba; Angleži, Nizozemci, Kitajci, itn.), (2) dela, ki se osredotočajo na posamezne dobrine, $\mathrm{s}$ katerimi so trgovali $\mathrm{v}$ Kantonu Guangzhouju 广州 (čaj, porcelan, svila, lakirani izdelki, itn.), (3) dela, katerih rdeča nit so družbeni, literarni in kulturni doprinosi kantonske trgovine in (4) dela, ki se osredotočajo na posamezno geografsko področje, denimo Makao ali Kanton. Nekatera dela se hkrati dotikajo več tu zgoraj navedenih tematik preučevanja.

Namen pričujoče razprave je predstaviti zgodovino razvoja politike mandžurskega dvora glede urejanja meddržavnih političnih in trgovinskih odnosov, ki je pomembno vplivala na formulacijo sistema kantonske trgovine. Mandžurska osrednja oblast je bila v obdobju svoje vladavine trdno prepričana, da Kitajska predstavlja središče kulturnega in civiliziranega sveta, zato je vztrajala pri tributarnih pravilih urejanja odnosov s sosednjimi deželami. Takšne prakse so uporabili tudi za urejanje evropsko-kitajske trgovine, ki se je skoncentrirala $\mathrm{v}$ Kantonu. Vztrajanje pri tributarnih odnosih je postopoma poglabljalo nesoglasja z zahodnimi državami, saj so slednje iskale načine, da bi se Kitajska na podlagi »bolj zahodnih pravil igre« odprla zunanjemu svetu ter se vključila v mednarodno trgovino in diplomacijo. Razprava izpostavi nekatere izmed spornih momentov trgovanja tako v Kantonu kakor tudi na kitajskih kopenskih mejah, ki so bili predvsem posledica togega političnega sistema mandžurske oblasti, ki se bodisi ni

\footnotetext{
${ }^{2}$ Nekaj dnevnikov je danes dostopnih tudi v knjižni obliki, kot na primer The Chronicles of the East India Company Trading to China, 1635-1834, avtor je Hosea Ballou Morse, ali delo z naslovom The Canton-Macao Dagregisters - 1762, avtor je Paul A. Van Dyke. Pri slednjem gre za dnevnik ladij Aschat, Admiraal de Ruyter in Vrouwe Petronella Maria, ki so pripadale nizozemski floti Vzhodnoindijske družbe.
} 
znala bodisi ni hotela prilagoditi družbenim in gospodarskim spremembam, ki so od začetkov osemnajstega stoletja dalje temeljito preobražale preostali svet.

\section{Kratek zgodovinski pregled razvoja pomorske trgovine in njenih institucij na Kitajskem}

Pomorska trgovina je že od časa dinastije Tang 唐 (618-907) dalje predstavljala pomemben vidik kitajske zunanje politike. Hkrati z vključitvijo Cesarstva sredine $\mathrm{v}$ pomorsko trgovanje je na Kitajskem prišlo do ustanovitve novih institucij, kot na primer Vrhovnega nadzorstva nad tujim trgovskim ladjevjem (angl. Superintendency of Foreign Shipping) ter Pomorske carinske uprave Haiguan 海 关 (angl. Maritime Customs Collectorate). Za potrebe nastanitve tujih trgovcev so ustanavljali tuje četrti s skorajda ekstrateritorialnimi pravicami, vodilni kitajski trgovci pa so pobirali davke $\mathrm{z}$ naslova pomorske trgovine. Vse to odseva pragmatičen značaj kitajskega zgodnjega upravljanja in nadzora nad pomorsko trgovino. Na tujem so kitajski trgovci, ki so pluli na svojih džunkah ${ }^{3}$, vzpostavili mrežo trgovskih postojank in naselbin, ki so za časa dinastije Yuan 元 (1271-1368) segale do obal Malabarja ${ }^{4}$. Pomorske kampanje dinastij Yuan in Ming 明 (13681644) so kitajski udeležbi v pomorski trgovini na tujih obalah dodale diplomatske in vojaške dimenzije. Izdelavo celovitejše politike o pomorskih trgovinskih povezavah in urejanju odnosov z državami, s katerimi so trgovali, je dvakrat vmes prekinila bolj nujna potreba po utemeljitvi upravičenosti prenosa nebeškega mandata na dve tuji vladavini, prvič na mongolsko dinastijo Yuan, drugič pa na mandžursko dinastijo Qing 清 (1644-1911). Obakrat je šlo za obmejna ljudstva, ki so jih Kitajci od nekdaj smatrali za barbare ${ }^{5}$. Weng zagovarja mnenje, da je ravno tu potrebno iskati vzroke, da sta poslednji kitajski dinastiji Ming in Qing dajali večji poudarek na vzpostavitvi osrednjega nadzora nad obmejnimi ljudstvi na svojih kopenskih mejah, kot pa da bi razvili širši zunanjepolitični koncept, ki bi med drugim uredil tudi vprašanja pomorske trgovine, odnosov s tujimi narodi ter nadzora državnih pomorskih meja:

Hence the reinterpretation of China's foreign policy in the Ming and Ch'ing within the traditional framework of the restoration of traditional suzerainty

\footnotetext{
${ }^{3}$ Džunka je malajska beseda za ladjo.

${ }^{4}$ Jugozahodni del Indijske podceline.

${ }^{5} \mathrm{~V}$ kitajskem jeziku fangui 番鬼 ali tudi guizi 鬼子.
} 
over the peoples on land frontier rather than the development of a grander imperial concept which would have also encompassed the new maritime frontier and perhaps prompted a different response and a new world order. (Weng 1997, 319)

Zaradi tega lahko kitajsko zunanjo politiko v obdobjih dinastij Ming in Qing dojamemo $\mathrm{v}$ sklopu njenih tradicionalnih okvirov; zunanjepolitična prizadevanja so bila namreč usmerjena $\mathrm{k}$ ponovni vzpostavitvi nadzora nad ljudstvi na kopenskih mejah, ne pa toliko k razvoju širšega koncepta, ki bi upošteval tudi nove pomorske meje in bi kot tak morda spodbudil drugačen odziv ter nastanek novega svetovnega reda.

Do poznega šestnajstega in zgodnjega sedemnajstega stoletja, ko so Evropejci dosegli azijske obale, so bile kitajska pomorska trgovina ter njihove trgovske postojanke tako rekoč povsod navzoče, njihove pomorske in diplomatske sposobnosti pa so bile nazorno prikazane azijskemu svetu. Toda zunanja politika ni bila izdelana do te mere, da bi utrdila prisotnost Kitajske $\mathrm{v}$ deželah, s katerimi so trgovali, da bi trgovske postojanke spremenila v kolonije, da bi si pridobila nadzor nad viri proizvodnje in da bi branila na novo osvojene meje. Trgovina in trgovske postojanke na tujem so bile tako izključno pod nadzorom zasebnih kitajskih trgovcev, mehanizmi urejanja politike trgovanja na obalah same Kitajske pa so bili v poznem Mingu v rokah lokalnih uradnikov ter vplivnih trgovcev. V zgodnjem obdobju dinastije Qing (1644-83) je mandžurski dvor skušal vzpostaviti osrednjo oblast nad obalo, toda takojšen rezultat so preprečile uporniške dejavnosti. Nadzor nad trgovanjem in stiki s tujci so tako ostali v rokah vodilnih trgovcev, ki sta jih v tistem času podpirali predvsem vplivni družini Shang 尚 in Geng 耿 iz Guangdonga 广东 in Fujiana 福建.

\section{Značilnosti mandžurske politike urejanja meddržavnih odnosov in pomorske trgovine}

Pričujoče poglavje bo podrobneje predstavilo sledeče karakteristike, ki so bistveno zaznamovale mandžursko formulacijo političnih direktiv glede vprašanj urejanja odnosov $\mathrm{z}$ drugimi državami ter pomorske trgovine: (1) prevzemanje praks dinastije Ming, predvsem s področij tributarne politike ter odnosa konfucijanstva do trgovine, (2) neskladnost med uradno predpisanimi političnimi direktivami cesarskega dvora in neformalnimi praksami, ki se jih je v Kantonu posluževal tako uradniški aparat kakor tudi sloj trgovcev, (3) oblikovanje politike, usmerjeno v 
eliminacijo notranjih in zunanjih groženj osrednji mandžurski oblasti, (4) oživitev in propad zasebne trgovine kitajskih trgovcev, (5) pojav in vzpon evropske trgovine, (6) obdobje med letoma 1684 in 1757, za katerega je značilen bolj ohlapen nadzor nad vsemi trgovskimi dejavnostmi, ki niso sodile v ožji okvir tributarnega sistema, in ki je $\mathrm{v}$ zgodovinskih razpravah označeno $\mathrm{s}$ terminom "politika odprtih vrat«, (7) znake naraščajočih restrikcij v kitajski zunanji politiki, ki kulminirajo $\mathrm{v}$ določbi, s katero se vsa zunanja trgovina omeji zgolj na kantonsko pristanišče.

\subsection{Prevzemanje praks dinastije Ming}

Kot kopenska vojaška sila, ki ni imela veliko izkušenj s pomorsko trgovino ter z urejanjem mednarodnih odnosov, se je mandžurska oblast uvodoma zgledovala po praksah, ki so bile v veljavi že za časa dinastije Ming. Ko je Mandžurom leta 1647 uspelo pacificirati Guangdong, so državam, ki so prejšnji dinastiji izkazovale tribut, svetovali, da nadaljujejo s tributarnimi odnosi in da so hvaležne za kitajsko naklonjenost. Edikt cesarja Shunzhija 顺治 iz leta 1647 jasno nakazuje morebitno vojaško posredovanje $\mathrm{v}$ primeru, če te dežele ne bi sprejele podrejenega položaja in kitajskih pravil urejanja mednarodnih odnosov:

If the various nations in the Southern seas and in the neighbourhood of Kwangtung, for example, Siam and Annam, will offer tribute to us, and will sincerely submit to our civilization and be vassal states, the court will not shoot a single arrow towards them, but will treat them as graciously as we treated Korea. (Fu 1966a, 6)

Če nam bodo različni narodi $\mathrm{z}$ območja južnih morij in dežel iz okolice Guangdonga, kot sta na primer $\mathrm{Siam}^{6}$ in $\mathrm{Anam}^{7}$, prinašali tribut, se iskreno podredili naši civilizaciji ter bili naši vazalni podložniki, potemtakem dvor $\mathrm{v}$ njihovo smer ne bo izstrelil niti ene puščice, ampak jih bo obravnaval dobrohotno, kot smo dobrohotno obravnavali tudi Korejo. ${ }^{8}$

Pobiranje davkov in pristojbin z naslova pomorske trgovine ter nadzor nad tujo trgovino sta bila od leta $1530 \mathrm{v}$ domeni okrožnega pomorskega prefekta haidao 海 道 (angl. Maritime Prefect ali Circuit Intendant). Pomorski prefekti so bili

\footnotetext{
${ }^{6}$ Današnja Tajska.

${ }^{7}$ Današnji Vietnam.

${ }^{8}$ Še pred mandžursko osvojitvijo Kitajske so Koreja in nekatera mongolska plemena pričela Mandžurom v znak podložnosti plačevati tribut.
} 
podrejeni provincijskim guvernerjem fuyuan 抚 院 $^{9}$, slednji pa generalnim guvernerjem zongdu 总督, ki so v času dinastije Qing vladali dvema provincama ${ }^{10}$. Generalni guverner province Guangdong je imel pod nadzorom še sosednjo provinco Guangxi 广西, njegov naziv v kitajščini je bil Liang Guang zongdu 两广 总督 ${ }^{11}$. Vsi položaji so izvirali še iz časa dinastije Ming, mandžurski dvor jih je prevzel in vključil v svoje administrativne prakse.

Na podlagi praks, prevzetih od dinastije Ming, je temeljilo tudi mandžursko obravnavanje trgovine in odnosov z Evropejci, ki so s Kitajsko trgovali že v poznem Mingu - v tistem obdobju so s svojimi trgovskimi dejavnostmi na ozemlju Kitajske bili prisotni predvsem Nizozemci, Portugalci in Rusi. Weng izpostavi, da pri vzpostavljanju trgovine in odnosov z Rusi mandžurski dvor ni imel veliko smernih točk, na katere bi se lahko oprl, in da so temelje kitajsko-ruskih odnosov postavili prav Mandžuri (prim. Weng 1997, 320).

Leta 1653 je mandžurski dvor od Nizozemcev, ki so zahtevali avdienco pri cesarju, zahteval predložitev dokazov, ki bi kazali na njihovo podložnost in podarjanje tributa prejšnji dinastiji Ming. Ker o takem odnosu zapisi niso obstajali, je bilo misiji naročeno, naj se vrne s priporočilnimi pismi nizozemske vlade, če želi, da bo sprejeta v »kitajsko družino narodov«. Ko so Nizozemci leta 1655 zadovoljili vsem zahtevam dvora, jim je bilo dovoljeno trgovanje na kitajskem ozemlju, v zameno za ta privilegij pa so dvoru vsakih 8 let prinašali tribut. $O$ nizozemski misiji je v svojem pismu guvernerju provinc Guangdong in Guangxi Li Qifengu 李栖凤 leta 1653 Shen Shi 沈时, takratni okrožni pomorski prefekt, takole zapisal:

Now the people of Holland, a country that has never embraced our culture and has never communicated with us, admire justice and have come to submit. They wish to follow our "calendar"" . This indeed has never happened before. $[\ldots]$ The first question that I asked was whether or not they had a memorial and native tribute for His Majesty. To this they replied that they wished only to compliment the Two Princes and to imitate other nations by presenting a tribute and applying for permission to trade. (Fu 1966a, 11)

\footnotetext{
${ }^{9} \mathrm{~V}$ kantonskem dialektu fohien.

${ }^{10}$ Izjema je bila prestolniška provinca Zhili 直隶, današnja provinca Hebei 河北, ki je imela svojega generalnega guvernerja.

${ }^{11} \mathrm{~V}$ kantonskem dialektu so ga imenovali tsjonton, tujci pa so zanj uporabljali naziva Jan Tok ali John Tuck.

${ }^{12}$ Izraz follow the calendar se nanaša na časovni interval med dvema zaporednima tributarnima misijama posamezne države.
} 
Ljudstvo iz Nizozemske, države, ki nikoli ni sprejela naše kulture in ki nikoli ni navezala stikov z nami, zdaj občuduje našo pravičnost in se nam želi podrediti. Radi bi sledili našemu »koledarju«. To se še nikoli prej ni zgodilo. [...] Najprej sem jih vprašal, ali prihajajo s priporočilnimi pismi in tributom za cesarja. Njihov odgovor je bil, da se želijo zgolj pokloniti princema, z izročitvijo tributa posnemati druge narode ter zaprositi za dovoljenje za trgovanje.

Takšna ortodoksna politika je prevladovala tudi na severnih mejah. Koreja je bila mandžurska tributarna država še iz časov pred mandžursko polastitvijo kitajskega prestola. Ko so Mandžuri tudi uradno prevzeli oblast, je bila ena izmed korejskih tributarnih obveznosti pošiljanje vojaških nabornikov, ki so se borili proti Rusom. $\mathrm{Na}$ drugi strani so tudi ruske tributarne misije morale sprejeti kitajska pravila urejanja medsebojnih odnosov. Misija Baikova ${ }^{13}$ je bila leta 1656 odslovljena ravno zaradi upiranja predpisanim oblikam izražanja podrejenosti in pokornosti. Ker je iz obdobij prejšnjih dinastij obstojalo le malo dokumentov, ki bi pričali o uradnih stikih med Kitajsko in Rusijo, Weng trdi, da so osnove kitajsko-ruske politike in njihovih medsebojnih odnosov razvili Mandžuri, prav tako izpostavi dejstvo, da je bila formulacija celovitejše pomorske politike mandžurskega dvora sekundarnega pomena, saj so se morali ukvarjati z vseskozi prisotno grožnjo možnosti kitajsko-ruskega vojaškega spopada na kopenskih mejah (prim. Weng 1997, 321).

Mandžurska oblast je po pretresih ob koncu dinastije Ming ponovno utrdila model tradicionalne konfucijanske družbe. Najnižji družbeni sloj so zaradi konfucijanskega preziranja trgovine kot nemoralne dejavnosti predstavljali ravno trgovci shangren 商人; vodilni sloji dinastije Qing so bili nadalje mnenja, da trgovina povzroča nerede ter razmah piratstva in razbojniških dejavnosti. Kljub formalno nizkemu položaju na družbeni lestvici je bil materialni položaj trgovskega razreda bistveno boljši - med najbolj premožnimi so bili tisti, ki so se v Kantonu ukvarjali z zunanjo trgovino. Nesorazmerje med njihovim nizkim formalnim in visokim dejanskim položajem je povzročalo, da kljub bogastvu niso imeli zagotovljene družbene varnosti. Bolj varne razmere in povezavo z vodilnimi sloji so si trgovci skušali zagotoviti s podkupovanjem, nakupi diplom ter zemlje; slednji so pomenili garancijo in odskočno desko za študijske kariere njihovih

\footnotetext{
${ }^{13}$ Cilj te ruske misije je bil zbrati podrobne informacije o kitajski trgovinski dejavnosti, še zlasti so želeli dognati, ali svilo in žamet dejansko proizvajajo na Kitajskem, ali morda to blago v državo Kitajci uvažajo od kod drugod. Misija Baikova naj bi tudi nakupila vzorce posameznega kitajskega trgovskega blaga. (prim. Sladkovskii 2008, 10)
} 
potomcev in sorodnikov. Kljub temu je bil trgovski sloj pogosto tarča nenadnih sprememb gospodarske politike, izrednih davkov, konfiskacij in izsiljevanja s strani uradništva. (prim. Saje 2004, 22)

\subsection{Neskladnost med direktivami mandžurskega dvora in praksami lokalnih uradnikov}

Uradni dvor se je naslanjal na zastarelo politiko dinastije Ming, ki je trgovanje s tujimi deželami in politične odnose z njimi vzdrževala na podlagi konvencionalnih tributarnih pravil, kar je poglabljalo navzkrižja z zahodnimi silami, posledično pa je takšno vztrajanje pri preživetih pravilih urejanja medsebojnih odnosov dinastijo pahnilo v dokončen propad. Mandžurski dvor je te prakse brez pomislekov sprejel in nadaljeval, vse dokler se ni ob koncu osemnajstega stoletja izkazalo, da je tributarni sistem že popolnoma izčrpan, saj Kitajska več ni imela politične moči za njegovo dosledno uveljavljanje, po drugi strani pa so takrat že vsi glavni trgovski tokovi potekali mimo pravil, kakršne je za izmenjavo blaga določal tributarni sistem. ${ }^{14}$ Lokalni uradniki so težili k vzdrževanju že obstoječih neformalnih praks, katerih glavni namen je bil ustvarjati čim večji dobiček; skladnost teh praks z uradno politiko je bila postranskega pomena. Tako je na primer $\mathrm{v}$ južnih pristaniščih že $\mathrm{v}$ poznem Mingu prevladala politika nevmešavanja $\mathrm{s}$ strani uradnega dvora, praktično so nadzor nad trgovino v rokah imeli lokalni uradniki in vplivni zasebni trgovci. Oboji so tudi pod mandžursko oblastjo težili $\mathrm{k}$ ohranjanju takšnih praks, saj so jim slednje zagotavljale višje prihodke od trgovinske dejavnosti. Na ta način so bogatele že tako vplivne trgovske družine in koruptivno lokalno uradništvo, obalni populaciji pa je bil zagotovljen vir preživljanja. Lokalno uradništvo je dvor vseskozi prepričevalo, da vzpostavljanje novih trgovinskih povezav s tujci in ohranjanje že obstoječih bogati kitajski narod ter zvišuje dohodke in življenjski standard ne samo v Kantonu in ostalih za trgovino odprtih pristaniščih, temveč tudi nasploh na Kitajskem. V takšnem tonu je napisano tudi pismo iz leta 1647 Tong Yangjiaja 佟养甲, takratnega generalnega guvernerja provinc Guangdong in Guangxi. V njem cesarju Shunzhiju razlaga koristi evropsko-kitajske trgovine v Makau (Aomen 澳门) in Kantonu:

While the [traders of the] foreign ships and the native merchant princes competed with one another in business, the people were benefited, and the

\footnotetext{
${ }^{14}$ Tudi evropsko-kitajska trgovina, ki se je skoncentrirala v Kantonu, ni sodila v tributarni sistem.
} 
annual customs duties yielded 22,000 liang ${ }^{15}$ of silver. In no year was there a shortage of money. [...] Before long the Chinese merchants were drained of money; goods no longer circulated, the people became impoverished, and the customs duties were reduced to little more than 1,000 liang. Thus it was clearly demonstrated that if the people of Hao-ching-ao ${ }^{16}$ come to trade, Kwangtung profits; but if they do not come, then Kwangtung is impoverished. [...] Commerce is a way to enrich our nation and to open foreign trade is a special means of raising income [from taxation] in Kwangtung as well as China. (Fu 1966a, 7)

Ko so tuji trgovci in domači trgovski veljaki medsebojno tekmovali v poslu, je imelo ljudstvo od tega koristi, carinske pristojbine pa so na letni ravni nanesle 22.000 liangov srebra. Ni bilo leta, ko bi denarja primanjkovalo. [...] Kmalu so kitajski trgovci ostali brez denarja; blago več ni krožilo, ljudje so obubožali, carinske pristojbine pa so se znižale na nekaj več kot 1.000 liangov. To je jasen znak, da Guangdong beleži dobiček, če pridejo sem trgovat ljudje iz Makaa; v nasprotnem primeru Guangdongu grozi obubožanje. [...] Trgovanje je način, kako obogatiti naš narod, $z$ odprtjem in obdavčitvijo zunanje trgovine pa lahko dobičke povečamo ne samo v Guangdongu, pač pa tudi nasploh na Kitajskem.

Čeprav se je mandžurski dvor zavedal, da evropsko-kitajska trgovina na obalah južne Kitajske polni državno blagajno, je vseeno imel pomisleke glede okrepitve trgovinskih odnosov in posledično povečane prisotnosti tujcev na kitajskem ozemlju, saj se je bal morebitnih sporov, ki bi lahko ogrozili trdnost njihove vladavine. Razlike med mandžurskim dvorom in lokalnimi uradniki glede urejanja teh vprašanj ter prepad med uradno politiko in neformalnimi praksami, ki so bile $\mathrm{v}$ veljavi v južnih pristaniščih, so v naslednjih 150 letih pomembno vplivale na mandžursko urejanje pomorske politike, posledično pa tudi na obravnavanje zunanjepolitičnih vprašanj nasploh.

\subsection{Eliminacija notranjih in zunanjih groženj mandžurskemu dvoru}

V prvem desetletju svoje vladavine se je mandžurski dvor ukvarjal predvsem z zatiranjem gibanja za obnovo dinastije Ming, ki je potekalo pod geslom »upreti se dinastiji Qing, obnoviti dinastijo Ming (fan Qing fu Ming 反清复明)《. Voditelji gibanja so poskusili dvigniti obsežnejši upor, vendar brez uspeha, saj so ga

\footnotetext{
${ }^{15}$ Liang 两: kitajska tradicionalna merska enota za srebro. 1 liang $=37.8$ gramov.

${ }^{16}$ Hao-ching-ao 壕镜澳 = Makao. V Makau je bilo takrat že močno razvito trgovanje s Portugalsko in Španijo, koristi te trgovine je bil deležen tudi bližnji Kanton.
} 
Mandžuri hitro zatrli. Protagonisti gibanja so se po porazu umaknili na Tajvan (Taiwan 台湾), kjer so v izolaciji vztrajali vse do leta 1683.

Najbolj nevaren izziv za mandžursko oblast je bil upor treh kitajskih vojskovodij San fan zhi luan 三藩之乱. V zgodnjih letih svoje vladavine so imeli Mandžuri namreč velike težave pri vzpostavljanju neposredne oblasti v kitajskih južnih provincah, zlasti v Fujianu, Guangdongu in Yunnanu 云南. Dvor je zato sprožil politiko, ki je generalom ${ }^{17}$ predhodne dinastije Ming omogočila, da so v mandžurskem imenu vladali Kitajcem $\mathrm{v}$ omenjenih provincah; ta praksa je znana pod imenom »naj Han Kitajci vladajo Han Kitajcem« (yi Han zhi Han 以汉制汉). V boju za še večjo avtonomijo in oblast so se generali leta 1673 uprli ter se začeli zavzemati za obnovitev dinastije Ming. Po hudih bojih so jih Mandžuri dokončno porazili leta 1681.

Z zmago nad lojalističnim gibanjem na Tajvanu leta 1683 so Mandžuri zaključili proces konsolidacije svoje oblasti na celotnem kitajskem ozemlju. Kljub trdni mandžurski oblasti pa je med posameznimi zavednimi izobraženci, ki niso hoteli sodelovati z Mandžuri in niso hoteli sprejeti ponujenih državnih služb, še vedno tlel kitajski nacionalizem. Saje piše, da je prav prenos oblasti v roke tuje mandžurske dinastije vzpodbudil prve oblike hanskega nacionalizma. (prim. Saje 2004, 10)

Tedanje razmere so bile dodatno napete zaradi možnosti upora obalne populacije, zaradi nenehno prisotne možnosti spora z Rusi in džungarskimi Mongoli na kopenskih mejah Kitajske ter zaradi možne vojaške intervencije nizozemskih pomorskih sil. Situacija, s katero se je na začetku svoje vladavine soočal mandžurski dvor, je bila v marsičem podobna razmeram, ki so prevladovale $\mathrm{v}$ poznem Mingu. Mandžuri so za rešitev problemov uporabili metode, ki se jih je poslužila že prejšnja dinastija: leta 1656 so prepovedali prekomorsko trgovino, obalno populacijo pa so kmalu zatem nasilno preselili v notranjost dežele.

Weng izpostavi, da je med politiko dinastije Ming in mandžurskim načinom urejanja razmer vseeno obstajala razlika; po njegovem mnenju sta bili prepoved trgovine in nasilna preselitev obalne populacije obrambni taktiki poznega Minga, da bi tako zopet vzpostavili nadzor nad obalo, ki so ga opustili desetletja poprej, medtem ko so Mandžuri ti isti taktiki uporabljali v pozitivnem smislu, da bi

\footnotetext{
${ }^{17} \mathrm{Wu}$ Sangui 吴三桂 je vladal v provincah Yunnan in Guangxi, Shang Kexi 尚可喜 v provinci Guangdong, Geng Zhongming 耿种明 pa je vladal v Fujianu.
} 
namreč utrdili osrednjo oblast nad obalo in njenimi prebivalci, še preden bi prišlo do neredov (prim. Weng 1997, 321). Tudi notranjih groženj Mandžuri niso dojemali zgolj $\mathrm{v}$ smislu razbojniških in roparskih dejavnosti, ampak so jim pripisovali nov pomen, namreč nasprotovanja tuji vladavini. Ko je Mandžurom leta 1683 le uspelo vzpostaviti mir, so obalno populacijo znova preselili nazaj na obale, preklicali so prepoved prekomorske trgovine, za zunanjo trgovino so odprli štiri pristanišča ${ }^{18}$. Na ta način je dvor obnovil tradicionalno prakso omogočanja preživljanja obalnemu prebivalstvu.

Nova politika je služila nevtralizaciji opozicijskih gibanj znotraj meja Kitajske, njen cilj je bil hkrati tudi vzpostaviti nadzor nad vse večjo prisotnostjo Evropejcev v južnih kitajskih pristaniščih in njihovimi zahtevami po okrepitvi trgovinske izmenjave med deželami. Cilj takšne politike je bil torej eliminirati tako domače kakor tudi tuje grožnje mandžurski vladavini.

\subsection{Oživitev in propad zasebne trgovine kitajskih trgovcev, vzpon pristanišč v ustju Dolge reke (Changjiang 长江) ter v Fujianu in Guangdongu}

Po letu 1684, ko so Mandžuri utrdili svojo oblast, je dvor pričel posvečati posebno pozornost dogajanju na južnih obalah Kitajske. Razvijali so politiko, ki je v prvi vrsti poudarjala pomen vzdrževanja miru in reda na obalah, manj pa so se osredotočali na vzpostavljanje takšnih praks, ki bi se ukvarjale specifično z vprašanji pomorskih, političnih in trgovinskih povezav Kitajske s tujimi državami. Preklic prepovedi prekomorske trgovine je povzročil hitro rast zasebne trgovine kitajskih trgovcev, ki so s svojimi džunkami pluli na obale Japonske, Manile ${ }^{19}$, Batavie $^{20}$, Siama in Indokine ${ }^{21}$; ta trgovina je nadaljnjih 50 let predstavljala večino prometa na obalah Kitajske. Nadzoru nad zasebnimi trgovci, gibanjem džunk ter nad blagom, ki so ga slednje prenašale, je mandžurski dvor pripisoval več pomembnosti kot pa vzpostavitvi uradnih odnosov z deželami, s katerimi so trgovali. Pomorska trgovinska dejavnost je bila $v$ tistem obdobju skoncentrirana na

\footnotetext{
${ }^{18}$ Pomorske carinske uprave so bile vzpostavljene v Guangdongu, Fujianu, Zhejiangu 浙江 ter v provinci Jiangsu 江苏.

${ }^{19}$ Manila, pristaniško mesto na Filipinih.

${ }^{20}$ Batavia, današnja Džakarta, glavno mesto Indonezije. Ime Batavia je bilo v veljavi za časa nizozemske kolonialne ere.

${ }^{21}$ Indokitajski polotok, na katerem ležijo države Tajska, Laos, Vietnam, Kambodža.
} 
obalah Fujiana in Guangdonga, z upadanjem zasebne trgovine ${ }^{22}$ pa se je pomorski promet preusmeril na pristanišča Ningbo 宁波, Zhoushan 舟山, kasneje tudi na Suzhou 苏州. Trgovanje z Malacco ${ }^{23}$, Manilo in Batavio je potekalo preko pristanišč Xiamen 厦门 in Quanzhou 泉州.

Guangzhou in Shantou 汕头 sta prednjačila kot pristanišči, v katerih je potekalo trgovanje z jugovzhodnimi azijskimi državami, kot sta bili na primer Siam in Indokina. Ko je leta 1727 dvor izdal odlok, da se morajo džunke, ki trgujejo na obalah jugovzhodne Azije, vračati bodisi $\mathrm{v}$ Xiamen bodisi $\mathrm{v}$ Guangzhou, se je trgovanje na obalah južne Kitajske le še ojačalo. Tudi evropska trgovina se je skoncentrirala $\mathrm{v}$ Kantonu. Prvotni cilj dopuščanja evropskokitajskega trgovanja v Kantonu je bil gospodarska oživitev južne Kitajske. Kanton je nato polagoma, a vztrajno, pridobival sloves pristanišča, v katerem so razmere za trgovanje ugodne, kar je posledično $\mathrm{v}$ regijo privabilo še več tujih ladij, $\mathrm{v}$ samem Kantonu in njegovem zaledju pa se je skoncentrirala močna obrtna in rokodelska skupnost. $\mathrm{O}$ naraščajočem pomenu kantonskega pristanišča med evropskimi trgovci, zlasti med angleškimi in francoskimi, piše tudi Weng: »..., do leta 1705 je postal Kanton priljubljeno pristanišče tako Angležev kot Francozov, kar je k selitvi v to mesto vzpodbudilo tudi vezilce svile« (Weng 1997, 322-3).

Van Dyke dodaja, da je edinstven položaj Kantona bil posledica njegove geografske lege ter bližine pristanišča Makao, ki je za sabo že imel bogate izkušnje trgovanja $\mathrm{z}$ evropskimi deželami, predvsem s Portugalsko in Španijo. Kantonske oblasti so tako tudi na podlagi teh izkušenj v osemnajstem in zgodnjem devetnajstem stoletju spretno krmarile med zahtevami evropskih trgovcev in uradnega Pekinga:

In the early years of the eighteenth century, Canton quickly emerged as one of the most flexible places to negotiate business. While it was not what one would consider "free" or "open", and not always consistent from one year to the next, the terms that could be agreed upon in Canton were almost always more beneficial than any that foreigners could find in other Chinese ports. [...] No other Chinese port proved to be as good as Canton in simultaneously accommodating trade and addressing the concerns of Beijing.

V zgodnjih letih osemnajstega stoletja je Kanton hitro pridobil sloves enega bolj ugodnih mest za trgovanje. Pristanišče sicer ni bilo popolnoma

\footnotetext{
${ }^{22}$ Od leta 1730 dalje na kitajskih obalah beležimo vse večjo prisotnost evropskih pomorskih trgovcev, kar je povzročilo postopen upad zasebne trgovine kitajskih trgovcev.

${ }^{23}$ Malezijska južna regija.
} 
»svobodno« ali »odprto«, tudi razmere za trgovanje so se v njem iz leta v leto spreminjale, pa vendar so se ponavadi tujci prav v Kantonu lahko dogovorili za najboljše pogoje trgovanja. [...] Nobeno drugo kitajsko pristanišče ni zmoglo tako uspešno kot Kanton hkrati zadovoljiti zahtevam trgovanja ter na drugi strani zahtevam Pekinga. (Van Dyke 2005, 5-6, 167)

Podobno kot Van Dyke in Weng tudi Chen Bojian 陈柏坚 in Huang Qichen 黄启 臣 izpostavljata, da je Kanton med vsemi za zunanjo trgovino odprtimi pristanišči imel najpomembnejšo vlogo:

在这四个对外贸易的口岸中, 以广州口岸最为重要。这是由于广州对外 贸易的悠久历史和得天独厚的地理位置所决定的。

Med temi štirimi za zunanjo trgovino odprtimi pristanišči je bil Kanton najpomembnejši. To dejstvo gre pripisati njegovi dolgi zgodovini na področju zunanje trgovine ter geografski legi, ki jo zaznamujejo odlične naravne razmere. (Chen in Huang 1995, 237)

V nasprotju z zasebno trgovino kitajskih trgovcev, ki je hitro narasla, a ravno tako hitro zatonila, je evropska trgovina od svojih začetkov dalje vseskozi beležila rast. Še zlasti je bila ta rast očitna, ko je kitajska zasebna trgovina v 30-ih letih osemnajstega stoletja dokončno propadla. To je evropskim trgovcem omogočilo, da so prevzeli del trgovskih poslov kitajskih zasebnikov, ki so poprej nadzorovali izmenjavo blaga med Kantonom in trgovskimi postojankami jugovzhodne Azije.

Oživitev in nato propad kitajske zasebne trgovine ter skoncentriranje trgovinske dejavnosti $\mathrm{v}$ pristaniščih $\mathrm{v}$ ustju Changjianga ter $\mathrm{v}$ Fujianu in Guangdongu so dejavniki, ki so pomembno zaznamovali zgodnje in srednje obdobje zgodovine pomorske politike dinastije Qing.

\subsection{Pojav in vzpon evropske trgovine}

Nova evropska trgovina na obalah južne Kitajske, ki je kasneje postala domena hong trgovcev ${ }^{24}$, predstavlja naslednjo značilnost zgodovine preučevanega obdobja. Pred letom 1640 so bili gospodarji trgovanja na obalah južne Kitajske Nizozemci, Portugalci in Španci, po omenjenem letu pa so večino poslov prevzeli

\footnotetext{
${ }^{24}$ Beseda hong izhaja iz kantonskega dialekta, v kitajskem jeziku gre za besedo hang 行, ki pomeni 'trgovino' ali 'trgovsko združenje'.
} 
Angleži in Francozi ${ }^{25}$ Čeprav je prvotno nekaj trgovanja potekalo med azijskimi kolonialnimi pristanišči in Kantonom, se je ta trgovina postopoma razvila v glavnem v bilateralno evropsko-kitajsko trgovanje. Najpomembnejše kitajsko izvozno blago je bil čaj; v Evropi, zlasti v Angliji, se je namreč močno razširila navada pitja tega napitka, a ga $\mathrm{v}$ tistem obdobju še niso pridelovali drugje kot na Kitajskem.

Tako bilateralno trgovanje kakor tudi trgovanje s čajem sta bili povsem novi značilnosti kitajske trgovine. Trgovski posli, odnosi s tujci ter pobiranje davkov so bili pod nadzorom lokalnih oblasti. Ker so vsi tujci morali poslovati le preko hong trgovcev, po mnenju mandžurskega dvora ni bilo potrebe po vzpostavitvi formalnih diplomatskih odnosov med Kitajsko in posameznimi državami, ki so z njo trgovale. Izdelavo celovite in dolgoročne politike, ki bi formalno uredila področja tuje trgovine in gospodarskih ter političnih povezav s tujci, je osrednja kitajska oblast postavljala na stranski tir. Dogovori v Kantonu so bili predvsem merkantilističnega značaja, v prvi vrsti je bilo pomembno ustvarjati dobiček, pobirati davke in pristojbine ter obalni populaciji zagotavljati možnost preživetja, pozornost mandžurskega dvora pa je bila usmerjena $\mathrm{v}$ zagotavljanje reda in varnosti na svojih obalah. Ti dejavniki so onemogočali vzpostavitev celostne prekomorske trgovinske politike.

Regulation of foreign relations and trade on the coast reflected Ch'ing sensitivities and priorities, but the focus on a maritime frontier security and containment policy pre-empted the development of a more active overseas policy. (Weng 1997, 324)

\footnotetext{
${ }^{25}$ Po velikih zemljepisnih odkritjih v šestnajstem stoletju sta Španija in Portugalska, predvsem na račun svojih z zlatom bogatih kolonij, postali najmočnejši državi na svetu. Imeli sta nepremagljivo ladjevje in zelo močno vojsko. Kmalu pa se je politični in vojaški položaj obeh iberskih držav močno spremenil, saj sta dobili tekmeca. Na Nizozemskem, ki je bila v tistem času pod španskim jarmom, je namreč v šestnajstem stoletju prišlo do revolucije. Trgovinsko in industrijsko razvite nizozemske province so se z najbogatejšo in zelo gosto naseljeno Holandsko na čelu ločile od Španije in se spremenile v močno, neodvisno državo. Trgovinska središča so se preselila v to deželo, Španija in Portugalska pa sta posledično vse bolj zaostajali in slabeli. Izgubili sta tudi pomemben del svojih kolonij. Prvenstvo je tako prevzela Nizozemska, ki je v nadaljevanju vodila izredno obširno trgovinsko politiko. Toda tudi ta položaj ni dolgo trajal. V boj za svetovno prvenstvo sta poleg Nizozemske vstopili namreč tudi Anglija in Francija. Za okrepitev Anglije je imela ogromen pomen revolucija, ki je omogočila hiter razvoj industrije ter kmetijstva, politično oblast pa prenesla v roke buržoaznega parlamenta. V času angleške buržoazne revolucije je Cromwell začel vojno proti Nizozemski, ki sta jo angleška mornarica in vojska porazili. Nato je Anglija pričela dolg, trdovraten boj s Francijo, v katerem je bila premoč na strani Angležev. Zadnja velika vojna, tako imenovana sedemletna vojna (1756-1763), je Angliji prinesla odločilno zmago. V 1763. letu, ko sta v Parizu državi podpisali mirovni sporazum, je Francija Angliji oddala svoje najpomembnejše kolonije v Indiji in Kanadi. Te pridobitve so znatno okrepile trgovinsko in kolonialno moč Anglije.
} 
Način urejanja odnosov in trgovanja s tujimi državami na kitajskih obalah je odražal prioritete in občutljiva politična vprašanja dinastije Qing, toda njihova osredotočenost zgolj na zagotavljanje varnosti na pomorskih mejah ter na politiko omejevanja sta zavirali oblikovanje bolj aktivne prekomorske politike.

Obseg evropske trgovine $\mathrm{v}$ Kantonu je vztrajno naraščal. Večino prometa $\mathrm{v}$ kantonskem pristanišču je predstavljala trgovina pooblaščenih evropskih družb, med katerimi je prednjačila Vzhodnoindijska družba (Dong Yindu gongsi 东印度 公司, angl. East India Company). Britansko trgovino, ki je v Kantonu do sredine osemnajstega stoletja obsegala že več kot polovico vse kitajske trgovine z zahodnimi državami, in je zato imela dokaj monopolen položaj, Weng izpostavi kot zadnjo pomembno razvojno smernico tega obdobja:

The expansion of the country trade between England and China based on cotton and later opium was ultimately the most important development which eventually provided the momentum for change in the system. (Weng 1997, 323)

Razširitev obsega trgovine med Anglijo in Kitajsko, ki je temeljila na poslovanju $\mathrm{z}$ bombažem in kasneje $\mathrm{z}$ opijem, predstavlja najbolj pomembno razvojno usmeritev, ki je v svoji končni fazi zagotovila odločilen moment za spremembo sistema.

\subsection{Politika odprtih vrat}

Od leta 1684 do 1757 je mandžurski dvor vzdrževal politiko odprtih vrat. Večina kitajske trgovine z vzhodnoazijskimi, južnoazijskimi ter evropskimi deželami ni sodila $\mathrm{v}$ tributarni sistem, saj mnoge države tega območja tributarnih odnosov zaradi novih možnosti trgovanja niso več potrebovale, zato so mandžurskemu dvoru prenehale pošiljati tribut. $\mathrm{V}$ očeh dvora se je omenjena trgovina razlikovala od uradne trgovine ${ }^{26}$, ki je bila dovoljena državam, ki so na kitajski dvor nekatere bolj redko, druge pač pogosteje - pošiljale tributarne misije. Toda ravno trgovina, ki je potekala zunaj okvirov tributarnega sistema, je bila konec koncev tista, ki je uničila zasebno kitajsko trgovino, in ki je mandžurskemu dvoru pokazala na nujnost sprememb na področju urejanja vprašanj mednarodnih političnih in trgovinskih povezav.

\footnotetext{
${ }^{26}$ Uradna trgovina je izraz, ki se uporablja za tiste trgovinske dejavnosti, ki so potekale znotraj okvirov tributarnega sistema, vse ostale oblike trgovanja pa so sodile v tako imenovano neuradno trgovino.
} 
Med letoma 1684 in 1699 so kantonske lokalne oblasti uspele prepričati uradni dvor, da so v Makau in Kantonu znižali višino dajatev in pristaniških pristojbin. $\mathrm{Na}$ ta način so omogočili porast trgovinske dejavnosti v regiji, kar je posledično zagotovilo višje državne dohodke in višji življenjski standard obalne populacije. Nadzor nad trgovanjem je bil v rokah lokalnega uradništva, cesarski dvor je zgolj potrjeval njihove odločitve ter $\mathrm{v}$ redkih primerih spreminjal in urejal zakonodajo na tem področju. Postopki lokalnega uradništva so bili ohlapno nadzorovani, Weng navaja, da je bil denimo prvi carinski presežek zabeležen šele leta 1727, aktivna udeležba uradnikov v trgovanju pa ni bila kaznovana vse do leta 1732 (prepovedana šele leta 1759), čeprav so na ta način kršili tradicionalni kodeks vedenja, predpisan za uradniški aparat (prim. Weng 1997, 324-5).

V Kantonu so torej po letu 1683 prevladale pragmatično naravnane lokalne prakse; političnih nazorov mandžurskega dvora glede trgovanja in mednarodnih odnosov, ki so še vedno poudarjali pomen tributarnih odnosov, povečini niso upoštevali. Dvor se je tega sicer zavedal, a glede na to, da so bila dogajanja v Kantonu predaleč od Pekinga, obveščenost pristojnih služb o dejanski situaciji v tem pristanišču pa slaba, se v prestolnici niti niso zavedali pomembnosti urejenih odnosov z zahodnjaki, niti jih ta problematika ni posebej zanimala.

\subsection{Znaki naraščajoče restrikcije v kitajski zunanji politiki}

Od 30-ih let osemnajstega stoletja dalje, ko je evropska trgovina že predstavljala večino prometa na obalah Kitajske, je v kitajski zunanji politiki zaslediti bolj restriktivne poteze. To v svoji razpravi o prekomorski trgovini med Kitajsko in Veliko Britanijo v zgodnjem obdobju dinastije Qing izpostavi tudi Chen Shangsheng, ki primerja trgovinski politiki obeh omenjenih držav in zaključi, da je bila kitajska restriktivna, britanska pa ekspanzionistična in protekcionistična:

通过比较可以看出, 清朝与英国在海外贸易政策上的差别, 从政策倾向 性上说是一种限制海外贸易和促进海外贸易的根本差别。

Iz primerjave politik prekomorske trgovine na eni strani mandžurskega dvora in na drugi strani Velike Britanije lahko vidimo, da je temeljna razlika v tem, da je bila prva restriktivno, druga pa ekspanzionistično usmerjena. (Chen 2010, 66) 
Do leta 1755 so bile vloge vseh kitajskih akterjev trgovanja v Kantonu (hong trgovcev, kompradorjev ${ }^{27}$, prevajalcev, dobaviteljev s celine, lastnikov trgovin) opredeljene tudi $\mathrm{z}$ zakonom. Prav tako je bila do tega obdobja legalizirana monopolistična struktura kantonske trgovine. Država je namreč pooblastila trgovska združenja yang hang, ki so edina lahko trgovala s tujci in so bolj znana kot hongi. Vsako od tujih ladij, ki so priplule v kantonsko pristanišče, je pod svoje okrilje prevzel eden od hong trgovcev, ki je potem tudi skrbel za varnost ladje ter njene posadke in blaga. $\mathrm{V}$ imenu tujcev je opravil vse formalnosti, pobral vse dajatve in pristaniške pristojbine, po opravljenih formalnostih prevzel blago, nato pa cesarskemu odposlancu $\mathrm{v}$ Kantonu in vladi $\mathrm{v}$ Pekingu poravnal visoke trgovinske dajatve. Naloge hong trgovcev so jasno razvidne iz spodnjega zapisa, ki ga je leta 1726 podal Robert Hewer iz belgijske trgovske pooblaščene družbe Ostend General India Company ${ }^{28}$ :

We [...] made Cudgin \& Suqua ${ }^{29}$ undertake to be our Protectors and Guardians, for it is always necessary at this Port, in cases of any Disputes or Quarrel with the Government, or any other People, occasion'd by your trade, Sailors or other ways, to have a Principal Merchant or Merchants, who undertakes to be answerable for all your actions, and is always ready to be called upon for that purpose. (Van Dyke 2005, 11-12)

Trgovski združenji Cudgin in Suqua smo pooblastili za naše skrbnike. V tem pristanišču je namreč v primeru kakršnih koli nesoglasij ali sporov bodisi z vlado bodisi z drugimi akterji trgovanja potrebno imeti predstavnika, ki se zaveže, da bo odgovarjal za vsa tvoja dejanja in bo vedno pripravljen, če ga s tem namenom tudi pokličejo.

V Kantonu so poslej trgovino urejali strogi državni predpisi, ki so omejevali svobodno delovanje tujih trgovcev, nadzor pa je dosegel višek, ko je cesar Qianlong 乾隆 leta 1757 izdal odlok ${ }^{30}$, da bo poslej Kanton edino odprto pristanišče za vso zunanjo trgovino:

\footnotetext{
${ }^{27}$ Komprador, v kitajskem jeziku maiban 买办. Beseda izvira iz portugalskega jezika in pomeni 'kupec', 'tisti, ki kupuje'.

${ }^{28}$ Originalni dokument hrani mestni arhiv v Antwerpnu, številka dokumenta IC 5757 (Stadsarchief, Antwerp, SAA: IC 5757).

${ }^{29}$ Cudgin (njegovo družinsko ime v kitajskem jeziku je Ye 叶) in Suqua (v kitajskem jeziku Chen Shouguan 陈寿官), dve izmed pomembnejših kantonskih trgovskih združenj ozir. hongov.

${ }^{30}$ Izdani odlok je bil odgovor na poskus Angležev leta 1755, da bi svojo trgovinsko dejavnost razširili tudi na pristanišče Ningbo $v$ Zhejiangu.
} 
粤省地窄人稠, 沿海居民大半籍洋船谋生, 不独洋行之二十六家而已。 且虎门, 黄埔在此设有官兵, 较之宁波之可经扬帆直至者, 形势亦异, 自以仍令赴粤贸易为正。本年来船, 虽已照上年则例办理, 而明岁赴浙 之船, 必以已意晓 谕蕃商, 以该督前任广东总督时兼管关务, 深悉尔等 情形, 凡蕃船至广, 即严饬行户, 善为料理, 并 无于尔等不便之处, 此该商等所素知。今经调任闽浙, 在粤在浙, 均所管辖, 无分彼此。但 此地向非洋船聚集之所, 将来止许在广东收泊交易, 不得再赴宁波。如 或再来，必令原船返棹至广，不准入浙江海口。预令粤海关传谕该 商等知悉。若可如此办理, 该督即以此意为咨文, 并将此旨加封寄示李 侍尧, 令行文该国总商, 遍谕蕃商, 嗣后口岸定于广东, 不得再赴 浙省。此于粤民生计, 并赣韶等关, 均有裨益, 而浙省海防, 亦得肃清。

Provinca Yue ${ }^{31}$ je po površini majhna, toda gosto poseljena. S tujo trgovino se ne preživlja zgolj 26 trgovskih združenj, ampak tudi večina tamkajšnjega obalnega prebivalstva. Prav tako so $\mathrm{v} \mathrm{Humenu}^{32}$ in na otoku Huangpu nameščeni uradniki in vojaki. Uradnikov in vojske v pristanišču Ningbo ni, zato lahko tuje ladje do pristanišča pridejo neovirano. Okoliščine v Ningboju se torej razlikujejo od tistih v provinci Yue. Od sedaj naprej velja moj ukaz, da morajo tuje ladje svoje trgovske posle opravljati v Guangdongu. Ladje, ki so ali pa še bodo prispele to leto, naj upoštevajo lanskoletne predpise. Toda tujim trgovcem, ki bodo prispeli $\mathrm{v}$ Zhejiang naslednje leto, je treba prenesti moja izrecna navodila, da od sedaj naprej tuja trgovina poteka izključno $\mathrm{v}$ Guangdongu. Ker je sedanji generalni guverner Fujiana in Zhejianga vodil carinsko pomorsko upravo, ko je bil na položaju generalnega guvernerja province Guangdong, je podrobno seznanjen z Vašo ${ }^{33}$ situacijo. Ko so tuje ladje prihajale v Guangdong, je skrbno in natančno uredil vse zadeve v zvezi s tujo trgovino. Za Vas ta nov odlok torej ne predstavlja nobenih nevšečnosti, saj ste $\mathrm{z}$ razmerami trgovanja $\mathrm{v}$ Guangdongu že seznanjeni.

Omenjeni generalni guverner je sedaj premeščen v provinci $\mathrm{Min}^{34}$ in Zhejiang. $\mathrm{V}$ razmerah za trgovanje $\mathrm{v}$ Guangdongu in Zhejiangu sicer ni nobenih razlik, saj vse spada pod njegovo pristojnost. Toda ker se $\mathrm{v}$ tem kraju ${ }^{35}$ tuje ladje ponavadi ne zbirajo, jim je $\mathrm{v}$ bodoče dovoljeno sidrati in trgovati zgolj $\mathrm{v}$ Guangdongu. Ustavljanje v Ningboju je prepovedano. Če tuje ladje kljub temu priplujejo do Ningboja, jim vstop $\mathrm{v}$ pristanišča Zhejianga ne smete dovoliti. Ukazati jim je treba, da odplujejo nazaj v Guangdong.

Ta edikt vnaprej ukazuje uradnikom carinske pomorske uprave v Guangdongu, da omenjena navodila prenesejo tujim trgovcem. Če lahko stvari uredite na ta

\footnotetext{
${ }^{31}$ Drugo ime za provinco Guangdong.

${ }^{32}$ Humen in Huangpu, nadzorni strateški točki v delti Biserne reke.

${ }^{33}$ Nanaša se na tuje trgovce.

${ }^{34}$ Drugo ime za provinco Fujian.

${ }^{35}$ Mišljen je Ningbo.
} 
način, naj generalni guverner province Zhejiang zapečati ta odlok in ga pošlje Li Shiyaou ${ }^{36}$, slednji naj vsebino odloka sporoči nadzorniku carinske pomorske uprave Guangdonga, ta pa naprej tujim trgovcem; sporočite jim, da je od sedaj naprej za tujo trgovino odprto le pristanišče v Guangdongu in nič več tisto v Zhejiangu.

Koristi od tega odloka bodo imeli tako prebivalci province Yue kakor tudi prebivalci province Jiangxi, razbremenjena pa bo tudi obramba obale Zhejianga. (Qianlong v Xing 2002, 107)

Van Dyke pri razlagi dejstva, zakaj je ravno Kanton bil določen za center zunanje trgovine, opozori tudi na geografske značilnosti delte Biserne reke (Zhujiang 珠 江). Globok ugrez evropskih ladij je namreč v plitvih vodah reke ogrožal varnost plovbe. Tujci so se zato na poti do samega pristanišča morali zanašati na izkušnje rečnih krmarjev, kar je oblastem v Kantonu omogočilo popoln nadzor nad gibanjem ladij. (prim. Van Dyke 2005, 16-17)

Uzakonjene prakse in sporazume so po letu $1757 \mathrm{v}$ Kantonu bolj dosledno izvajali. Zdelo se je, da se mandžurski dvor vrača $\mathrm{k}$ ortodoksnim politikam urejanja mejnih vprašanj in mednarodnih odnosov, ki so temeljile na tributarnem sistemu; v slednjem je bilo trgovanje sekundarnega pomena, v prvi vrsti je bilo pomembno, da so dežele, ki so želele s Kitajsko navezati stike, sprejele podrejen položaj. Weng je mnenja, da je restriktivna politika kitajskega dvora bila predvsem posledica povečane prisotnosti Evropejcev na obalah južne Kitajske in vse večjega obsega evropsko-kitajske trgovine; dvor se je zato odločil področja trgovine in odnosov z evropskimi deželami urediti na bolj sistematičen način (prim. Weng 1997, 326). Tako je bil na primer leta 1759 ukinjen privilegij, ki je tujcem omogočal neposreden dostop do visokih lokalnih uradnikov. Povratek v ortodoksno politiko je bil po Wengovem mnenju $\mathrm{v}$ skladu tudi $\mathrm{z}$ intenzivno sinizacijo Mandžurov, ki je potekala nekako do sredine osemnajstega stoletja (prim. Weng 1997, 326). Mandžuri so namreč vse od začetkov svoje vladavine skušali vzpostaviti čimbolj dosledno podobo nekdanje kitajske družbe, da bi tako upravičili prenos dinastične oblasti v roke tujcev, na ta način pa so po mnenju mnogih zgodovinarjev upočasnili potek prehoda Kitajske $\mathrm{v}$ bolj moderno civilizacijsko obdobje, saj je popolna prevlada neokonfucijanizma ovirala vse poskuse ustvarjanja kakovostnega napredka in inovacij (prim. Saje 2004, 7).

\footnotetext{
${ }^{36}$ Generalni guverner provinc Guangdong in Guangxi v letih 1757-1758, 1758-1761, 1764-1765 ter 1767-1777. Zaradi koruptivnih dejanj je bil leta 1780 obsojen na smrtno kazen, ki pa jo je preklical sam cesar in jo spremenil $\mathrm{v}$ zaporno kazen.
} 
Uradne politične prakse po letu 1757 , ki so urejale odnose in trgovino $\mathrm{z}$ Evropejci, so nadomestile ad hoc lokalne določbe, ki so bile v veljavi v času, ko je evropska trgovina predstavljala zgolj majhen delež celotne kitajske trgovinske dejavnosti s tujimi deželami. Dvor je smatral, da mora povečano evropsko prisotnost $\mathrm{v}$ kitajskih južnih pristaniščih, zlasti $\mathrm{v}$ Kantonu, urediti $\mathrm{s}$ širšo nacionalno politiko, ki ne bo več prepuščena kratkoročnim pragmatičnim smernicam ter interesom lokalnih trgovcev in uradnikov.

Odziv dvora na poskus Angležev leta 1755, da bi vzpostavili trgovanje tudi v pristanišču Ningbo, nazorno ilustrira tu zgoraj povedano. Angleži so si sicer že v letih 1735-36 skušali utreti trgovske poti na Kitajsko prek pristanišč Xiamen in Ningbo, toda ker v tistem obdobju kitajski dvor Evropejcev še ni smatral za grožnjo državni varnosti, so tržnim silam pustili prosto pot, poskus pa je propadel sam od sebe, saj so bile razmere za trgovanje še zmeraj bolj ugodne v Kantonu.

Toda do leta 1755 je evropska trgovina obsegala že več kot polovico celotne kitajske trgovine $\mathrm{z}$ zahodnimi državami, zato je angleška ekspedicija v Ningbo grozila, da bo razširila evropsko prisotnost in njihove dejavnosti, kar je na dvoru sprožilo preplah. Angleži so se upirali cesarskemu odloku, ki je zunanjo trgovino omejil na pristanišče v Kantonu, dvor pa je njihovo vedenje označil za grožnjo in kljubovanje kitajskim zakonom. To je navajala tudi odredba cesarja Qianlonga iz leta 1759: »...niso se izognili poskusu, da bi nam grozili...«(Fu 1966a, 219).

Kljubovalno vedenje Evropejcev je bilo v kitajskih nacionalnih okvirih dojeto kot grožnja notranji varnosti in ozemeljski, tako kopenski kakor tudi pomorski, celovitosti. Te grožnje je bilo potrebno hitro eliminirati. Zopet je na površje vzniknil tudi strah pred sodelovanjem obalne populacije $\mathrm{s}$ tujci, izbruh vojne $\mathrm{v}$ Džungariji ${ }^{37}$ ter problemi z Rusi glede pobeglega Amursane pa so še dodatno

\footnotetext{
${ }^{37} \mathrm{~S}$ strateškega vidika je bilo za utrditev cesarstva na Kitajskem vedno najbolj pomembno ozemlje osrednje Azije, nomadska ljudstva tega področja so namreč lahko na hitro ustvarila močne plemenske zveze in vojaške formacije. Konec sedemnajstega stoletja so se tako močno okrepili zahodni (džungarski) Mongoli, ki so predstavljali glavno neposredno zunanjo nevarnost obstoječi kitajski oblasti. Ker se je v regiji osrednje in vzhodne Azije v tistem času kot nova sila pojavila tudi Rusija, se je tedanji kitajski cesar Kangxi 康熙 odločil z njimi skleniti premirje, da bi na ta način preprečil možnost rusko-mongolskega zavezništva ter nato neovirano pokoril džungarske Mongole. Slednji so do tedaj že nadzorovali vso džungarsko-tarimsko kotlino, zunanjo Mongolijo (ozemlje sedanje republike Mongolije), imeli so močno podporo v Tibetu ter so nevarno vdirali v vzhodne mongolske pokrajine nad Pekingom. Kitajci so jih odločilno premagali leta 1696 pri sedanjem Ulan Batorju ter na ta način postavili temelje za zasedbo in priključitev novih ozemelj, kamor se je v osemnajstem stoletju razširilo mandžursko cesarstvo. Vojaške akcije proti zahodnim Mongolom so se zaključile šele sredi osemnajstega stoletja, za časa vladavine cesarja Qianlonga, ko je mandžurska vojska pokorila še preostala uporna mongolska plemena ter tako vzpostavila trdno oblast nad
} 
obudili skrbi, s katerimi so se Mandžuri ukvarjali na začetku svoje vladavine, namreč možnosti vojne na dveh frontah. O pomembnosti zagotavljanja miru in varnosti na obalah Kitajske ter o nujnosti omejitve evropske prisotnosti zgolj na pristanišče v Kantonu pričajo tudi naslednji izseki iz treh ediktov cesarja Qianlonga:

1. However, if foreigners are hereafter allowed to have another market, we fear that in the course of time, those who remain in our Interior will increase in number. The coastal region is important to our national strategy. To allow them at Ning-po is not a good policy for there is no way to prevent their gradual penetration of the Interior. We should never forget to pay attention to this and we should plan how to inspect and patrol [the foreign ships] in order that violations of our laws will not occur in the future. (Fu 1966a, 200-1)

Če bo tujcem od zdaj naprej dovoljeno trgovati tudi v drugem pristanišču, se bojimo, da se bodo sčasoma tisti posamezniki, ki bodo ostali v notranjosti našega cesarstva, številčno okrepili. Obalna področja so pomembna za našo nacionalno strategijo. Sprostitev mednarodne trgovine v Ningboju ni dobra poteza, saj tujcem potem ne moremo nikakor onemogočiti, da ne bi postopno vdirali v notranjost naše dežele. $K$ temu moramo usmeriti našo pozornost, prav tako pa se moramo osredotočiti na izdelavo načrtov za nadzor nad tujimi ladjami, da se v bodoče ne bi soočali s kršitvami naših zakonov.

2. Our naval frontier safety is involved and we must study this thoroughly in order to stop the habit of disobedience. (Fu 1966a, 218-9)

Gre za našo varnost na pomorskih mejah. Temu vprašanju se moramo temeljito posvetiti, da bi preprečili neposlušnost.

3. Under the old regulations, the foreign ships always anchored at Macao of Kwangtung, without difficulty to us. Although we also have a maritime customs office at Ning-po of Chekiang, its purpose is different from that of Kwangtung. Moreover, the character of the Chekiang people is volatile, and if the foreign merchants live among them, unfortunate incidents may occur. If we do not make laws to prohibit it, we fear that in the future, foreign ships will arrive in greater number. Ning-po might again become a port where foreign ships assemble. The naval defence of our Interior is highly important. (Fu 1966a, 202)

Na podlagi starih uredb so se tuje ladje vedno zasidrale v Makau, ne da bi nam to povzročalo kakršne koli nevšečnosti. Čeprav imamo tudi v Ningboju

celotnim vzhodnim delom osrednje Azije do pogorja Pamir. Zadnjo veliko mongolsko vstajo proti dinastiji Qing je v letih 1755-56 vodil Amursana, v kitajskem jeziku Amuersana 阿睦尔撒那; po porazu je prebegnil v Rusijo, kjer je našel zatočišče. 
pomorsko carinsko upravo, se njen namen razlikuje od tiste v Guangdongu. Nadalje, značaj ljudi iz Zhejianga je nestanoviten in če bodo tuji trgovci živeli med njimi, se lahko pripetijo kakšni neljubi incidenti. Bojimo se, da bodo $\mathrm{v}$ prihodnosti, če z zakonom tega ne prepovemo, tuje ladje prihajale $v$ še večjem številu, Ningbo pa bi lahko tako znova postal njihovo zbirno pristanišče. Pomorska obramba naše notranjosti je izrednega pomena.

Vsi ti edikti so izpostavljali potrebo po sprejetju nacionalne politike, ki bi zagotavljala varnost na kitajskih obalnih predelih ter na njihovih pomorskih mejah. Dvor je bil namreč v skrbeh, da v primeru, da gibanja Evropejcev ne bodo skrbno nadzorovali, bo to slednjim omogočilo postopno vdiranje $\mathrm{v}$ notranjost dežele, kar bi zagotovo vodilo k neljubim zapletom (Fu 1966b, 200, 202).

Kitajski dvor je Evropejce vseskozi opozarjal na enosmerno (evropsko) korist trgovanja, saj samozadostna Kitajska skoraj ni potrebovala tujih izdelkov; dejstvo, da evropskim družbam sploh omogočajo trgovanje na kitajskem ozemlju, so venomer izpostavljali kot znamenje dobre volje in naklonjenosti dvora $v$ odnosu do njih:

They do not know that our Interior produces practically everything which we need so that we do not depend on their trade. We can provide a sufficient supply of our own consumer goods. (Fu 1966a, 219)

Ne vedo, da v notranjosti našega cesarstva proizvedemo skorajda vse, kar potrebujemo, tako da nismo odvisni od trgovinskih navez $\mathrm{z}$ njimi. $\mathrm{S}$ potrebnimi dobrinami se lahko $\mathrm{v}$ zadostnih količinah oskrbimo sami.

Nespoštovanje kitajskih zakonov in določb se zato v nobenem primeru ni smelo tolerirati, še več, takšna dejanja je bilo treba strogo kaznovati ter na ta način pokazati, kako deluje kitajski pravni sistem: »Tako bodo ljudje vedeli, kako resnično deluje naša pravičnost.« (Fu 1966a, 216)

Šlo je skratka za ortodoksno tradicionalno politiko, spisano na način, ki se je običajno uporabljal na področjih urejanja kopenskih mejnih vprašanj in tributarnih misij, ki so na Kitajsko prihajale po kopnem. Mandžurski dvor je tokrat takšno politiko prvič razširil tudi na svoje pomorske meje, uradni razglasi pa so vedno vsebovali svarilni podton. Omejitev zunanje trgovine zgolj na pristanišče v Kantonu je predstavljala popoln obrat od prejšnje politike nevmešavanja, ki je bila v veljavi med letoma 1684 in 1756; odločilen dejavnik, ki je sprožil uvedbo novih praks, pa je bil predvsem agresiven nastop Evropejcev ter razširitev njihovih trgovinskih dejavnosti. 
Težave, s katerimi so se soočali Mandžuri v sredini osemnajstega stoletja, so bile sicer podobne tistim $\mathrm{v}$ začetnih letih njihove vladavine. Razlika je bila v tem, da je bil sredi osemnajstega stoletja mandžurski dvor na višku svoje moči in je vstopal v novo, veliko bolj agresivno fazo potrjevanja svoje osrednje oblasti in varovanja svoje ozemeljske celovitosti, medtem ko je v letih osvajalne politike bilo primarnega pomena oblast konsolidirati ter pomiriti nemirne južne province. Cesar Qianlong je politike, ki so bile v veljavi od dinastije Han 汉 pa vse do dinastije Ming, označil za sramotne, saj naj bi bile preveč popustljive do tujih barbarov. Sam je zagovarjal nepopustljive in bolj trde politične prakse:

The way we control foreign vassals is this: If we treat them with courtesy, they become more arrogant; if we awe them with power, they naturally fear us. (Fu 1966a, 211-2)

Način, kako nadzorovati tuje vazale, je sledeč: če jih obravnavamo vljudno, bodo postali le še bolj arogantni; če pa jih navdamo $\mathrm{z}$ občutkom strahospoštovanja do naše moči, se nas bodo bali.

Skladno s t.i. politiko »pravilnega načina vladanja in nadzora nad njimi ${ }^{38}$ «(right way to rule and control them) so bile denimo prekinjene tudi trgovske vezi z Rusi, kot posledica ruske pomoči pri uporu in pobegu Amursane. Rusi so kasneje zahtevali odškodnino, kar je rezultiralo v podpisu dogovora v Kyakhti ${ }^{39}$ leta 1768. Medtem, ko so bili stiki z Rusi prekinjeni, se je mandžurski dvor zapletel v vojno in osvojitev Džungarije.

Bolj odločna politika mandžurskega dvora je bila implementirana v visokem Qingu sredi osemnajstega stoletja, ko je vlada bila zmožna narekovati pogoje trgovanja in urejanja medsebojnih odnosov. V eseju iz leta 1777 glede problemov z barbari je cesar Qianlong primerjal obe kitajski mejni področji, hkrati pa uradnike opomnil, da ker je Kitajska na višku svoje moči, tujci nikakor ne smejo kazati neposlušnosti, hkrati naj bi tudi kitajska oblast bila pravična in naj ne bi podpirala zgolj svojih ljudi na škodo tujih barbarov:

At the present time Our Empire is at her peak. The various barbarians fear and live in awe of Our power so that they dare not show disobedience. However, if we want preventive measures we must forthwith cease to allow the growth

\footnotetext{
${ }^{38}$ Nanaša se na tujce.

${ }^{39}$ Posledice podpisa sporazuma v Kyakhti so bile sledeče: (1) med Kitajsko in Rusijo so bile vzpostavljene diplomatske in trgovske vezi, ki so ostale v veljavi vse do sredine devetnajstega stoletja, (2) vsa mongolska ozemlja so bila dodeljena kitajskemu cesarstvu, (3) premirje z Rusijo je Kitajski omogočilo širitev proti zahodu in priključitev območij današnjega Xinjianga 新疆.
} 
of abuses. [...] where there is mutual trade with foreign merchants, all generals, viceroys and governors should act in accordance with our principles and seek ways of upholding them. Whenever there is a foreign negotiation or a lawsuit they should never support only our people to the injury of the foreign barbarians. (Fu 1966a, 278-8)

Naše cesarstvo je trenutno na višku svoje moči. Ta moč razne barbare navdaja s strahospoštovanjem, tako da si ti ne drznejo privoščiti neposlušnosti. Toda če želimo vpeljati preventivne ukrepe, moramo nemudoma preprečiti nadaljnjo rast zlorab. [...] kjer koli poteka poslovanje s tujimi trgovci, bi morali vsi generali, generalni guvernerji in guvernerji poiskati načine, kako pri poslih upoštevati naša načela. Kadar koli pride do pogajanj s tujci ali morebiti do tožbenega zahtevka, pa naj naši uradniki nikoli ne podpirajo zgolj naših ljudi v škodo tujim barbarom.

Druga polovica stoletja je pomenila predvsem vzdrževanje zunanjega videza nekdanje veličine in ohranjanje $\mathrm{v}$ preteklost vpete miselnosti. Vztrajanje pri nespremenjenih stališčih je ob koncu osemnajstega in na začetku devetnajstega stoletja privedlo do izjemne togosti v odzivanju na zahteve moderne dobe in izzive, ki jih je porajalo evropsko prodiranje na kitajsko ozemlje.

V 80-ih in 90-ih letih osemnajstega stoletja se je Kitajska namreč zopet soočala $\mathrm{s}$ težavami na praktično vseh mejah, mandžurski dvor pa je bil pri soočanju z njimi še bolj nepopustljiv. Uporabljali so prej omenjeno politiko, osnovano na vzbujanju strahospoštovanja (awe them with power), podkrepljeno $\mathrm{s}$ tradicionalno prakso odrekanja trgovskih privilegijev barbarom. Ko se je na primer v Kantonu v 80-ih letih osemnajstega stoletja pojavila nova kriza, šlo je za t.i. dolžniško $\mathrm{krizo}^{40}$, je ta znova sovpadala s težavami na severovzhodnih in severozahodnih mejah Kitajske.

Na severozahodu so tako denimo med letoma 1785-92 prekinili vse trgovinske povezave z Rusi, kar je leta 1792 privedlo do podpisa drugega sporazuma v Kyakhti. Prav tako je dvor zahteval ponovno vzpostavitev osrednje oblasti nad Tibetom, za katerega so smatrali, da že dolgo pripada njihovemu teritoriju (prim. Fu 1966a, 302). Angleži v Kantonu so bili nestrpni, potem ko je poravnava glede dolžniške krize v letih 1778-80 rezultirala $\mathrm{v}$ še bolj restriktivnem sistemu.

\footnotetext{
${ }^{40}$ Da so lahko hong trgovci pravočasno plačevali visoke trgovinske dajatve cesarskemu odposlancu v Kantonu in vladi v Pekingu, so si nekateri izmed njih denar posojali pri tujih trgovcih. Zaradi visokih obrestnih mer so nekateri hong trgovci še globlje zapadli v dolgove, ki jih kasneje niso mogli odplačati, posledično so tujci svoje odškodninske zahtevke naslavljali na mandžurski dvor. (prim. Van Dyke 2005, 96-97)
} 
Zahtevali so ublažitev razmer $\mathrm{v}$ Kantonu, odprtje večih pristanišč za zunanjo trgovino, prepustitev enega pristanišča $\mathrm{v}$ ekstrateritorialno upravljanje, prav tako so zahtevali vzpostavitev tujih diplomatskih predstavništev na ozemlju Kitajske. Angleškim zahtevam so se pridružile tudi druge evropske države. Rusi so po končani ozemeljski širitvi ter konsolidaciji oblasti v Sibiriji sledeč zgledu evropskih držav leta 1805 na mandžurski dvor naslovili zahtevo po zagotovitvi trgovinskih pravic v Kantonu, Nanjingu 南京 ter v ustju reke Amur, zahtevali pa so tudi ponovno vzpostavitev trgovine v Džungariji.

Vse misije so bile pri doseganju svojih ciljev neuspešne, saj bi v primeru, da bi mandžurski dvor tem zahtevam ugodil, to pomenilo popolno »obkolitev« Kitajske s strani Evropejcev ${ }^{41}$. V skladu s trdnim političnim izhodiščem, ki ga je sredi osemnajstega stoletja glede urejanja odnosov s tujimi državami zavzel uradni Peking, neuspeh tujih misij ni bil presenetljiv.

Zahodne države in njihove trgovske družbe so čedalje težje prenašale ozke okvire kitajskega urejanja trgovine in meddržavnih odnosov, zato so spori med njimi in kitajsko upravo dobivali čedalje večje razsežnosti. Evropske države so zahtevale mednarodne odnose na podlagi evropskega prava in zahodnih diplomatskih načel ter večjo svobodo trgovanja. Za vse te zahteve se Kitajska ni menila; mandžurska oblast je še vedno poudarjala kitajsko samozadostnost ter dejstvo, da Evropejcev niso sami vabili, če pa so že prišli, morajo sprejeti kitajska pravila urejanja mednarodnih odnosov.

Tako je denimo Macartneyeva misija leta 1793 bila predstavljena kot zapoznela tributarna misija za Qianlongov 80. rojstni dan, nizozemska misija leta 1795 pa naj bi nosila tribut za diamantni ${ }^{42}$ jubilej njegove vladavine. Obe misiji je dvor sicer vljudno sprejel, ju nastanil v Yuanmingyuanu 圆明园, ki jo je posebej za sprejem tributarnih misij dal zgraditi cesar dinastije Ming Yongle 永乐, toda nato sta bili misiji prav tako vljudno odslovljeni, dvor pa ni izpolnil niti ene njihove zahteve. Cesar je odgovoril naknadno, iz sloga njegovih ediktov, naslovljenih na angleškega kralja Georga III., pa lahko spoznamo tipičen odnos tedanje Kitajske do Evrope; ta je poudarjal kitajsko samozadostnost in togo vztrajanje pri svoji dinastični tradiciji (prim. Saje 2004, 55-56).

\footnotetext{
${ }^{41}$ Do takšne situacije je prišlo stoletje kasneje.

${ }^{42}$ 60. obletnica vladavine, kar po kitajskem verovanju predstavlja zaključen življenjski ciklus. Takšna razlaga sledi iz kitajskega štetja let na osnovi kombinacije desetih nebesnih debel in dvanajstih zemeljskih vej, kar predstavlja ciklus, ki se ponovi vsakih 60 let.
} 
Weng na tem mestu poudarja, da bi Angleži na neuspeh svoje misije lahko drugače odreagirali ter da bi že v tem obdobju lahko prišlo do vojaškega spopada med Anglijo in Kitajsko (prim. Weng 1997, 332). Kot razlog, zakaj do slednjega ni prišlo, navaja deljena mnenja angleške vlade ter Vzhodnoindijske družbe in njenih trgovcev. Slednji so nasprotovali kakršnim koli politikam, ki bi v Kantonu ogrozile njihove dobičkonosne trgovske posle, angleška vlada pa predvsem zaradi svojih lastnih pomislekov glede ideje o prostem trgovanju ni bila pripravljena poseči po orožju in vstopiti v vojno s Kitajsko. Slabega pol stoletja kasneje je bogateč angleški trgovski lobi, da bi razširil svoje trgovinske dejavnosti in dosegel ublažitev restriktivnih pogojev poslovanja, svojo vlado le prisilil v vojaško posredovanje. (prim. Weng 1997, 333)

Ortodoksna politika mandžurskega dvora je bila v obdobju po Qianlongu še bolj izrazita navkljub dejstvu, da je bil tributarni sistem proti koncu stoletja že popolnoma izčrpan. Ruska misija je bila leta 1805 odslovljena že na meji, saj se njen vodja Golovkin ni želel pokoriti tributarnim ritualom, prav tako je bila neuspešna naslednja angleška misija, ki jo je leta 1816 vodil Lord Amherst. V Peking so prispeli v času, ko so se Angleži bojevali v Nepalu, ki je bil kitajska tributarna dežela. Po proceduralnih zapletih je cesar Jiaqing 嘉庆 misijo odslovil brez avdience, kar je dodatno zaostrilo že tako napete razmere med Anglijo in Kitajsko. Cesar je sprva celo nameraval prekiniti trgovanje v Kantonu, vendar so ga visoki uradniki iz Kantona odvrnili od te namere. Angleški dvor se je po dveh neuspelih poskusih pogajanj čedalje bolj nagibal v smeri vojaškega spopada, ki naj bi spremenil obstoječe odnose s Kitajsko.

Napori po vzpostavitvi meddržavnih odnosov so bili od teh dogodkov dalje na mrtvi točki, medtem ko se je trgovanje $v$ Kantonu nadaljevalo. Po Wengovem mnenju je med akterji, ki so bili vpleteni v kantonski sistem trgovine, obstajalo veliko prikrivanja; slednje je bilo eno izmed osnovnih potez trgovanja, ki je konec koncev pomembno doprinesla tudi k padcu sistema, ki je živel dobrih 150 let:

There was deception all round: the court was deceived; the Europeans deceived themselves for the sake of the good relations needed for profitable trade; and the local officials and Hong merchants were deceivers for their own benefit. This was the stuff of which secular trade at Canton was made, and it differed from the prescribed form and national policy.

Laži so bile prisotne na vsakem koraku: dvoru se je marsikaj prikrivalo; Evropejci so slepili sami sebe zavoljo vzdrževanja dobrih odnosov, ki so predpogoj za dobičkonosno trgovino; lokalni uradniki in hong trgovci so prav 
tako zavoljo lastnih koristi slepili sami sebe. Takšno je bilo jedro stoletne trgovine $\mathrm{v}$ Kantonu in to se je razlikovalo od predpisane forme trgovanja in nacionalne politike s tega področja. (Weng 1997, 334)

\section{Zaključek}

Mandžuri sami sicer niso bili veliki inovatorji, so pa bili zato mojstri posnemanja in so prejšnje prakse s področja meddržavnih političnih in trgovskih povezav zlahka prikrojevali svojim trenutnim potrebam. Kopenske meje so do leta 1790 uspeli zavarovati s pomočjo sporazumov in uspešnih vojaških akcij v vzhodnem delu osrednje Azije, ki so zaključile proces širitve mandžurskega imperija in konsolidacije njihove oblasti. Glede na dejstvo, da so bili kopenska vojaška sila, so bili na svojih pomorskih mejah razmeroma nebogljeni; vse večja evropska prisotnost v južnih in vzhodnih kitajskih pristaniščih pa je dvoru dala slutiti, da bo največja grožnja njihovi vladavini prišla ravno po morju, zato so se vseskozi trudili, da bi na področjih varovanja svojih pomorskih meja ter odnosov s tujimi državami, s katerimi je v kitajskih lukah potekala izmenjava trgovskega blaga, razvili ustrezne politike.

Pri formulaciji mandžurske pomorske politike lahko izpostavimo naslednje dejavnike: (1) mandžursko neizkušenost na tem področju, posnemanje praks prejšnjih dinastij ter počasen razvoj lastnih praks, ki niso sledile svetovnim družbenim in gospodarskim spremembam, (2) pretirano poudarjanje zagotavljanja obalne varnosti $\mathrm{v}$ smislu eliminacije tako domačih kot tujih groženj mandžurski osrednji oblasti ter (3) vzpon in padec lastne kitajske prekomorske trgovine ter razširitev evropske trgovine v pristaniščih južne Kitajske.

Dovoljevanje tuje trgovine v kitajskih južnih provincah je bilo sprva del ožje politike, s katero je dvor želel pomiriti obalna področja, tamkajšnji populaciji omogočiti vir preživljanja ter na ta način eliminirati notranje dejavnike, ki bi v bodoče lahko spodkopali trdnost osrednje mandžurske oblasti. Zunanja grožnja vladavini dinastije Qing se je pojavila z vzponom evropske trgovine, urejanje področij pomorske politike in trgovine ter nadzor nad »tujimi barbari« pa sta na tej točki postala osrednja mandžurska preokupacija. Sprva pragmatično politiko, ki je bila za urejanje zunanje trgovine v veljavi v kitajskih južnih pristaniščih, so po letu 1757 nadomestile bolj restriktivne prakse. V slednjih so bili vidni tudi znaki naraščajoče sinizacije Mandžurov. Skrb za ohranjanje tradicionalnih 
konfucijanskih vrednot je med drugim povzročila, da je kitajski vladajoči sloj hitro izgubil stik s spremembami, ki so potekale na svetovnih družbenih, gospodarskih in političnih podijih in katerih znamenja so na Kitajsko v največji meri prinašali ravno evropski trgovci. Kitajska samozadostnost, prepričanost $\mathrm{v}$ svojo superiornost, zaničevanje vsega tujega in vztrajanje na, gledano z evropskega stališča, preživetih pravilih urejanja medsebojnih odnosov so bili napoti uveljavitvi trgovskih in političnih povezav med Kitajsko in evropskimi državami, kakor so si jih zamišljale slednje. Kitajska je namreč vztrajala pri tributarnem načinu urejanja odnosov, evropske dežele z Anglijo na čelu pa so želele stike vzpostaviti na podlagi zahodne diplomacije in prava. Kitajci se niso zavedali novosti v svetovni ureditvi, niso bili seznanjeni z mednarodnimi zakoni, niso se zavedali svoje vojaške zaostalosti in zaradi tega niso videli nobene koristi $\mathrm{v}$ enakopravnih mednarodnih povezavah. Vsi ti dejavniki so poglabljali nasprotja s tujimi državami, naposled pa privedli do vojaškega spopada z Anglijo.

Porazu, ki ga je v tem spopadu doživela Kitajska, je sledilo stoletje nadaljnjih kriz, nemirov in ponižanj $\mathrm{s}$ strani evropskih narodov. Na podlagi $\mathrm{v}$ pričujoči razpravi zapisanih zgodovinskih dejstev bi lahko trdili, da je bila Kitajska od te točke dalje praktično prisiljena poiskati svoj nov položaj v svetovnem družbenem redu. To je od nje zahtevalo, da se $\mathrm{v}$ določenih pogledih prilagodi zahodni civilizaciji, slednje pa je povzročilo temeljito preobrazbo kitajske družbe in miselnosti.

V zgodovinskem obdobju, ki ga zajema pričujoča razprava, so se torej polagali temelji za vključitev Kitajske v globalno družbo. Gospodarski, kulturni, politični in sociološki procesi, ki so potekali v tem času, so zagotovo bili eden izmed ključnih dejavnikov, ki so po eni strani povzročili »smrt« tradicionalne Kitajske, po drugi strani pa sprožili oblikovanje nove, moderne Kitajske in uresničitev Napoleonovih preroških besed.

\section{Summary}

The present article traces the development of particular policies which were used by the last imperial dynasty of China to handle foreign affairs and international trade relations. At the same time the article points out that these political formulations had an immense influence on the manner in which Chinese officials treated West-European merchants whose presence was increasingly growing in 
Chinese ports. As such these policies played a crucial role in the rise and fall of the Canton System of Trade.

The Manchus, being foreign conquerors, tried to maintain their own identity and traditions but largely left Chinese customs and institutions alone. By the end of the $17^{\text {th }}$ century, the Qing managed to eliminate all Ming opposition and put down a rebellion led by Chinese generals in the south. As rulers of the Middle Kingdom, the Manchus based their political organization on that of the Ming. By claiming that China was the center of the civilized world and was as such selfsufficient and had no need for foreign goods the Qing court insistently demanded that all merchants and political representatives coming from abroad must comply with the Chinese practice of regulating politics and trade based on the wellestablished tributary system. According to Confucian ideology, engaging in commerce was regarded as a dishonorable activity. Since it saw little or no benefit of overseas trade, China remained reluctant to actively engage in it and rather focused on securing its land borders. On the other hand, the European merchants wished to expand their trade activities in China and conduct political relations based on Western diplomacy and law. To these incentives, the Qing court answered with restrictive measures by officially allowing international trade only at the port of Canton. Since 1757, when these restrictions were put into effect, dissatisfaction among foreign traders grew with each passing decade. China, unaware of the economical, political and social changes that were taking place in the world of that period, adhered to its beliefs and political practices. The discrepancy between these two standpoints eventually culminated in an armed conflict and forced China to mould a different role for itself in this emerging interconnected new world.

\section{Literatura}

Chen, Bojian 陈柏坚, in Huang, Qichen 黄启臣. 1995. Guangzhou waimao shi 广州外贸 史 (Zgodovina tuje trgovine v Kantonu). Guangzhou: Guangzhou chubanshe.

Cheng, Shangsheng 陈尚胜. 2010. 'Qing chao qianqi yu Yingguo haiwai maoyi zhengce de chubu bijiao 清朝前期与英国海外贸易政策的初步比较' ('Primerjava politik prekomorske trgovine med Anglijo in Kitajsko v zgodnjem obdobju dinastije Qing'). Haijiao shi yanjiu 海交史研究 (官tudije s področja pomorske zgodovine) 1: 66-73. 
Fu, Lo-shu. 1966a. A Documentary Chronicle of Sino-Western Relations (1644-1820), Part I. Tucson: The University of Arizona Press.

- 1966b. A Documentary Chronicle of Sino-Western Relations (1644-1820), Part II. Tucson: The University of Arizona Press.

Morse, Hosea Ballou. 1926-1929. The Chronicles of the East India Company Trading to China, 1635-1834, 5 vols. Oxford: Clarendon Press.

Saje, Mitja. 2004. Zadnja dinastija in izzivi sodobnosti: zgodovina Kitajske od vdora Mandžurcev do ustanovitve ljudske republike. Ljubljana: Filozofska fakulteta Univerze v Ljubljani, Oddelek za azijske in afriške študije.

Sladkovskii, Mikhail Iosifovich. 2008. History of Economic Relations between Russia and China: from Modernization to Maoism. New Brunswick: Transaction Publishers.

Van Dyke, Paul A. 2005. The Canton Trade: Life and Enterprise on the China Coast, 1700-1845. Hong Kong: Hong Kong University Press.

- 2006. The Canton-Macao Dagregisters - 1762. Macau: Instituto Cultural do Governo da R.A.E. de Macau.

Weng, Eang Cheong. 1997. The Hong Merchants of Canton: Chinese Merchants in SinoWestern Trade. Richmond, Surrey: Curzon Press.

Xing, Yongfu 邢永福. 2002. Qing gong Guangzhou shisan hang dang'an jingxuan 清宫广 州十三行档案精选 (Izbrani dokumenti dinastije Qing o trinajstih trgovskih združenjih v Kantonu). Guangzhou: Guangdong jingji chubanshe. 